\title{
$\mathrm{Bi}$ 系バルク超電導体における 交流通電時の交流損失
}

\author{
岩熊 成卓, 川浪 精一, 和久田毅, 式町 浩二 \\ 木稲 博之, 船木 和夫*, 竹尾 正勝*, 山藤 馨 \\ 田中 靖三**, 三村 正直**, 植田 和雄***, 樋上 久彰**** \\ 九州大学工学部電子工学科 福岡市東区箱崎 6-10-1 \\ * 九州大学工学部附属超伝導科学研究センター 福岡市東区箱崎 6-10-1 \\ ** 古河電気工業侏研究開発本部日光研究所超電導応用研究部 日光市清滰町 500 \\ *** 踭富士電機総合研究所 横須賀市長坂 2-2-1 \\ **** 富士電機株エネルギー事業本部原子力事業部原子力技術部 川崎市川崎区田辺新田 1-1
}

（1993 年 10 月 21 日受理）

AC Loss in a Superconducting $\mathrm{Bi}-\mathrm{Sr}-\mathrm{Ca}-\mathrm{Cu}-\mathrm{O}$ Bulk Sample Carrying AC Transport Current

Masataka Iwakuma, Seiichi Kawanami, Tsuyoshi Wakuda, Kouji Shikimachi, Hiroyuki Konomi, Kazuo FunaKi,*

Masakatsu TAKeO,* Kaoru Yamafuji, Yasuzou TANAKa,**

Masanao Mimura, ${ }^{* *}$ Kazuo UedA*** and Hisaaki HiUE****

Department of Electronics, Faculty of Engineering, Kyushu University 36, 6-10-1 Hakozaki, Higashi-ku, Fukuoka 812

* Research Institute of Superconductivity, Kyushu University, 6-10-1 Hakozaki, Higashi-ku, Fukuoka 812

** Superconductivity Research Department, Nikko Research Laboratory,

The Furukawa Electric Co., Ltd., 500 Kiyotaki, Nikko 321-14

*** Fuji Electric Corporate Research and Development Ltd., 2-2-1 Nagasaka, Yokosuka 240-01

**** Engineering Department, Nuclear Power Division, Fuji Electric Co., Ltd., 1-1 Tanabeshinden, Kawasaki-ku, Kawasaki 210

(Received October 21, 1993)

\section{Synopsis :}

It is shown that the observed value of the AC loss of a cylindrical BSCCO bulk superconductor with the diameter of $9.6 \mathrm{~mm}$, carrying the $\mathrm{AC}$ transport current with the frequency of $60 \mathrm{~Hz}$, deviates noticeably from the theoretical values estimated from the critical state model. It is clarified that this deviation results from the fact that the internal distribution of flux density, $B(r)$, is quite different from that predicted by the critical state model, when the AC transport current with the frequency, $f$, of $60 \mathrm{~Hz}$ is applied to the sample with a large diameter, $R$, and with a low $n$-value. This conclusion is based on the numerically simulated results of $B(r)$ obtained by solving the Maxwell equations using the observed $J_{\mathrm{c}}=J_{\mathrm{c}}(B)$ and $E(J)=E(0)\left(J / J_{\mathrm{c}}\right)^{n}$ characteristics for the DC electric field, $E$, the DC transport current density, $J$, and the DC critical current density, $J_{\mathrm{e}}$, determined by the criterion of $0.1 \mu \mathrm{V} / \mathrm{cm}$. Finally, a general numerical chart of the $\mathrm{AC}$ loss against $f R^{2} J_{\mathrm{c}}$ is presented for the various $n$-values, for the convenience of the design of the high- $T_{\mathrm{c}}$ current leads.

Keywords : AC loss, transport current, critical current, high $T_{\mathrm{c}}$, oxide superconductor 


\section{1.はじめに}

Bì 系超電導体は臨界温度が高いことから，将来発 電機や変圧器等電力機器への応用が期待されている。 しかしながら，現状では高温領域での臨界電流特性の 低下が著しいために，まずはその低熱伝導率に着目し て液体ヘリウム温度で動作するコイルの電流リードと しての開発が進められている1,2)。

Bỉ 系バルク超電導体を用いた交流用電流リードの 開発には，Bi 系バルク材の熱特性とともに交流通電 特性および通電時の交流損失特性をまず明らかにしな ければならない。従来, バルク超電導体に交流磁界お よび交流電流を印加した場合の電磁界と交流損失解析 は，ピン力すなわち臨界電流密度 $J_{\mathrm{c}}$ の磁界 $B$ 依存性に 種々のモデル3 7) (以下ピンカモデルと称する) を導 大して議論されてきた ${ }^{8 \sim 12)}$ 。最も詳細で汎用的なもの として，巨視的には一様な微細構造の無限平板に対し て大江・山藤が Irie-Yamafuji モデルを提唱して計算 したもの ${ }^{3)}$ ，円柱導体に対しては松下らが Irie-Yamafuji モデルに基づいて磁界印加上電流印加の場合の相 違を明確にして計算したもの ${ }^{12)}$ が挙げられる。しか し，従来行われた議論はいずれも準静的状況を仮定し た，すなわち狭義の臨界状態モデル13)が成立する状況 下のものであり，ダイナミックな状況下での考察はな されていない。

液体窒温度領域で動作する $\mathrm{Bi}$ 系バルク超電導体は 磁気的不安定条件が緩やかなために断面寸法すなわち 電流容量を大きくできる。また, 通電電流一定の条件 下では，試料を円柱形状とした場合，直径が大きいほ ど交流損失は小さくなり損失面でも得をする ${ }^{12)}$ 。しか し，断面寸法の大きなバルク材に商用周波の電流を印 加した場合には磁束侵入に伴う電界が大きくなり, $n$ 值が小さな場合には臨界電流密度 $J_{\mathrm{c}}$ 以上の 密度で電 流が流れることもあるであろう。また, 従来材料に適 応されたピンカモデルおよび交流損失の表式が $J_{\mathrm{c}}$ の 異方性や粒内，粒間での $J_{\mathrm{c}}$ の相違が存在する $\mathrm{Bi}$ 系 バルク超電導体に適用できるかも十分には検討されて いない。

そこで本研究では，まず $\mathrm{Bi}$ 系バルク超電導体に 60 $\mathrm{Hz}$ 交流電流を通電した際の交流損失を測定し，準静 的状況を仮定して導出された従来の理論表式と比較し た。次に，両者の相違の原因について，微小交流磁界 重畳法等補助実験ならびに通電時の電磁界および交流 損失の数值解析を行って考察し, Bi 系バルク超電導

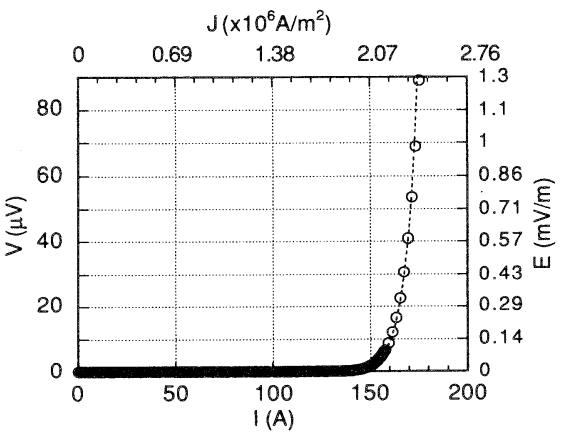

(a)

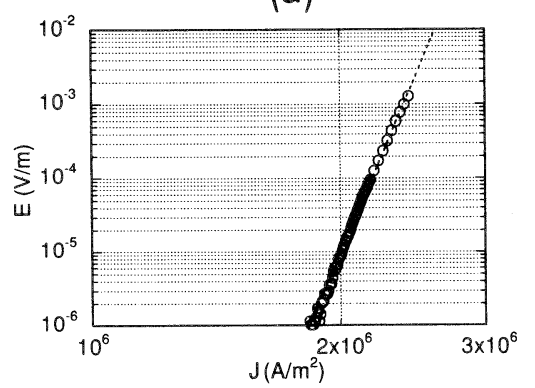

(b)

Fig. 1 (a) $V-I$ and (b) $E-J$ curves. The broken lines represent the approximate expression given by Eq. (1).

体の交流電流に対する応答特性を明らかにした。さら に一般的円柱状超電導体における交流通電時の交流損 失の周波数, $n$ 值依存性についても数值解析により考 察した。

\section{2. 試料}

試料は以下のように焼結法により作製した $\left(\mathrm{Bi}_{1-x}\right.$ $\left.\mathrm{Pb}_{x}\right)_{2} \mathrm{Sr}_{2} \mathrm{Ca}_{2} \mathrm{Cu}_{3} \mathrm{O}_{y}$ 組成のバルク超電導体である ${ }^{14)}$ 。 まず，原料粉を仮焼結，粉砕の後，100〜300 MPa の 圧力で泠間静水圧により成形した。これを $820 \sim 840^{\circ} \mathrm{C}$ で熱処理し，その後冷間静水圧と熱処理を数回繰り返 した。この反復段階の途中で焼結体を円柱形状に切 削し，試料両端に銀䇴を電極として巻き付けた。最終 仕上がり寸法は直径 $9.6 \mathrm{~mm}$, 長さ $140 \mathrm{~mm}$, 電極を 除いた長さは $100 \mathrm{~mm}$ である。

\section{3. 実験および数値解析}

測定はいずれも液体窒素中で行った。

\section{1 臨界電流}

臨界電流は外部磁界なしで直流電流を印加して四端 子法により測定した。電圧タップ間隔は $70 \mathrm{~mm}$ であ 


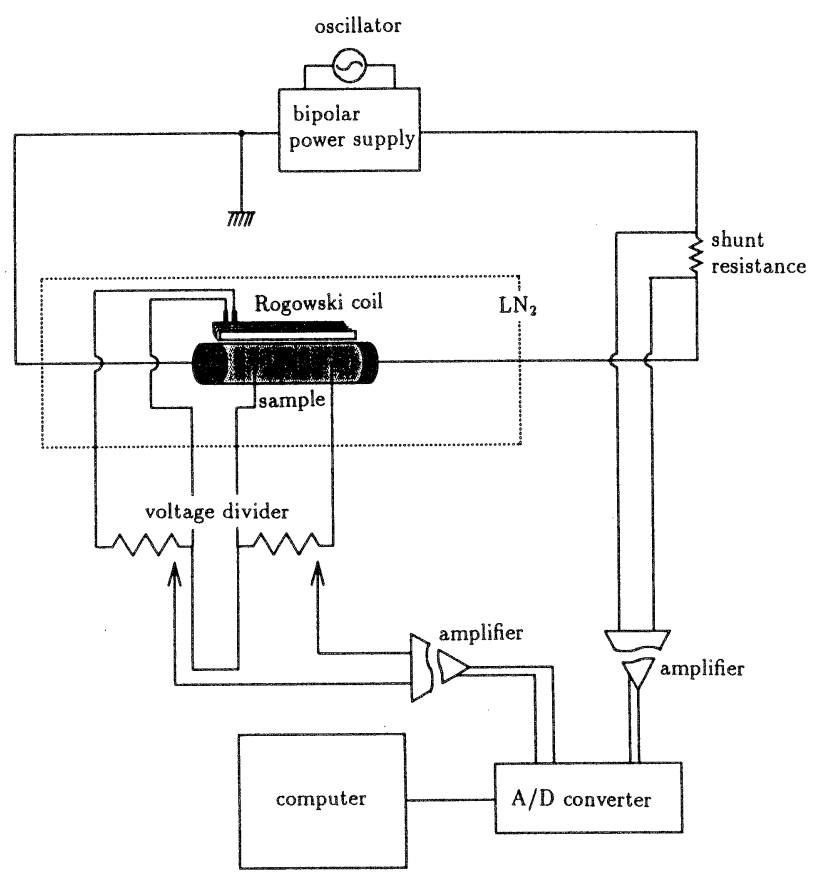

(a)

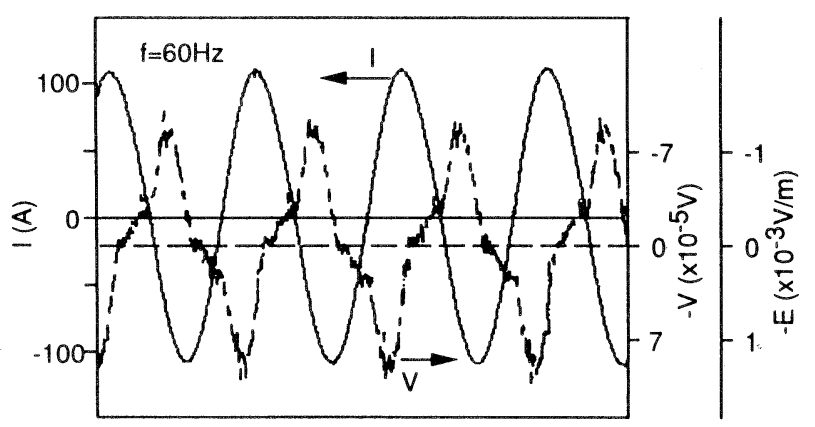

(b)

Fig. 2 Measuring system of AC loss in the cylindrical superconductor carrying ac transport current. (b) The observed current and voltage waveforms. Current peak is $110 \mathrm{~A}$.

る。Fig. 1 (a) に測定した電圧-電流特性を示す。臨界 電流 $I_{\mathrm{c}}$ はクライテリオンを $0.1 \mu \mathrm{V} / \mathrm{cm}$ とすると $145 \mathrm{~A}$ であった。これより求められる平均の臨界電流 密度 $J_{\mathrm{ca}}$ は $2.00 \times 10^{6} \mathrm{~A} / \mathrm{m}^{2}$ である。Fig. 1 (b) は Fig. 1 (a) を電界-電流密度 (以下 $E-J$ ) 特性として両 対数でプロットしなおしたものである。Fig. 1(a)(b)に 抒ける破線は,

$$
E=10^{-5}\left(\frac{J}{J_{\mathrm{ca}}}\right)^{26}
$$

を示したものである。E-J 特性は（1）式により近似 でき， $n$ 值は 26 である。

\section{2 交流通電時の交流損失}

本研究では測定系統図を Fig. 2 (a) に示す磁化測定 装置 ${ }^{15)}$ を用いて $60 \mathrm{~Hz}$ 正弦波電流を通電した場合の 交流損失を測定した。装置上磁化測定と異なるのは, 本来測定試料への侵入磁束を検出するために配置する 試料と非接触のピックアップコイルが臨界電流測定に 用いた電圧タップとなっていることだけである。電圧

低温工学 
タップで観測される電圧には試料外部に発生する円周 方法の磁界成分による誘導電圧も含まれる。ロゴスキ ーコイルは磁化測定と同様にこれをキャンセルし精度 のよい測定を行うために配置した。キャンセル抵抗は $10 \mathrm{k} \Omega$ とし, 分圧比は電流ピーク時に電圧がほぼ零に なるように選定した。交流損失は, 電流信号 $I$ と電圧 タップ間の電圧信号 $V$ を $\mathrm{A} / \mathrm{D}$ 変換器を介して平均 電流密度 $J_{\mathrm{a}}$ と表面電界 $E_{\mathrm{s}}$ の時系列配列として計算 機に取り込み, これらの内積を一周期分時間平均する ことにより単位体積当たりの損失パワーとして求め た。これは以下に示すように, 電圧タップ間の試料表 面に预けるポインティングベクトル $\left(-\boldsymbol{E}_{\mathrm{s}} \times \boldsymbol{H}_{\mathrm{s}}\right)$ の 一周期積分から単位体積当たりの平均損失パワーPを 求めたことにほかならない。

$$
\begin{aligned}
P & =\frac{1}{T} \int_{0}^{T} \frac{V(t)}{l} \frac{I(t)}{\pi R^{2}} d t \\
& =\frac{1}{T} \int_{0}^{T} E_{\mathrm{s}}(t) J_{\mathrm{a}}(t) d t \\
& =\frac{2 \pi R l \frac{1}{T} \int_{0}^{T} E_{\mathrm{s}}(t) \frac{\pi R^{2} J_{\mathrm{a}}(t)}{2 \pi R} d t}{\pi R^{2} l}
\end{aligned}
$$

$$
=\frac{\left(\begin{array}{l}
\text { Surface Area between } \\
\text { Potential Tap }
\end{array}\right) \frac{1}{T}\left|\int_{0}^{T} \boldsymbol{E}_{\mathrm{S}} \times \boldsymbol{H}_{\mathrm{S}} d t\right|}{\text { (Volume between Potential Tap })}
$$

ここで $\mathbb{H}_{\mathrm{S}}$ は表面磁界, lは電圧タップ間の距離, $T$ は周期， $R$ は試料半径である。

通電電流 $110 \mathrm{~A}$ (ピーク値) の場合の計算機に取り 込んだ電流㧍よびキャンセル後の電圧波形を Fig. 2 (b) に示す。表面電界はピークでは $1.33 \mathrm{mV} / \mathrm{m}$ と臨界電 流 $I_{\mathrm{c}}$ を定義したクライテリオンの 100 倍以上も大き な值となっている。Fig. 2 (b) に示した電圧波形は通電 電流ピーク值を $I_{\mathrm{c}}$ 以上でさらに大きくしていくと電 流ピーク付近で $I_{\mathrm{c}}$ 測定時と同様大きく上昇するよう になる。交流損失はこの上昇成分がほとんど目立たな い通電電流 $160 \mathrm{~A}$ (ピーク值) 以下で測定した。

測定した交流損失の電流ピーク值 $I_{\mathrm{m}}$ 依存性を Fig.3 に示す。Irie-Yamafuji モデル $\left(J_{\mathrm{c}}=\alpha B^{\gamma-1}\right)$ に基づく 履歴損失の理論值 ${ }^{12)}$ も Fig. 3 にピンパラメータ $\gamma$ が 0, 0.5, 1 の場合について実験值と比較して示してい る。Irie-Yamafuji モデル は $\gamma=1$ とおくとBean モ デル4)に一致し，この場合の履歴損失の理論值 ${ }^{12}$ ( (13) （14）式に後述）は Hancox により導かれた結果 ${ }^{9)}$ と 同じものである。従来材料に扔いては Irie-Yamafuji モデルを用いてピンパラメータ $\alpha, \gamma$ の最適化を行う

Vol. 29 No. 4 (1994)

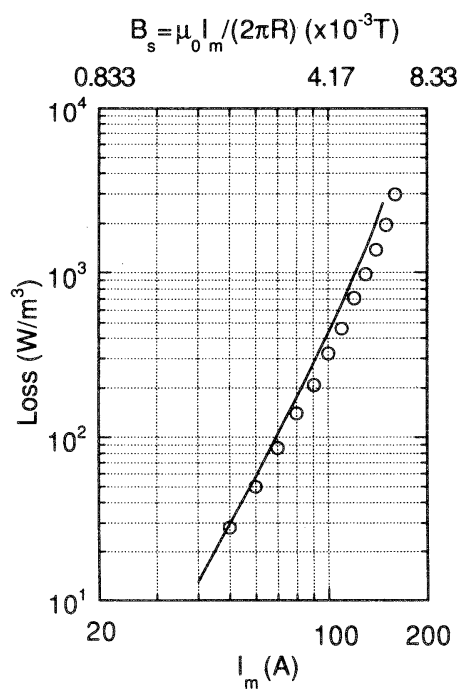

Fig. 3 AC loss versus peak value $I_{\mathrm{m}}$ of the ac current with a frequency of $60 \mathrm{~Hz}$. The solid, broken and chained lines represent the theoretical results ${ }^{12}$ from IrieYamafuji model for pin parameter $\gamma=1, \quad 0.5$ and 0 , respectively. The theoretical one for $\gamma=1$ is equal to that from Bean model. ${ }^{8)}$ The upper axis represents the peak value of the self-magneticfield $B_{\mathrm{s}}$ at the surface of sample.

ことにより履歴損失は理論とよく一致する ${ }^{16)}$ 。しか し, 測定した交流損失の電流值依存性は $\gamma=1$ すなわ ち Bean モデルに基づく理論曲線に近いものとなって いるが，交流損失は全電流振幅において理論值の半分 程度である。

\section{3 微小交流磁界重畳法による $\boldsymbol{J}_{\mathrm{c}}$ 測定}

3.2 節で述べたように, 交流電流通電時の 交流損失 は従来のピンカモデルを用いた理論表式とは一致して いない。焼結法により作製された酸化物超電導体にお いて誘起される遮蔽電流は, Y系超電導体でよくみら

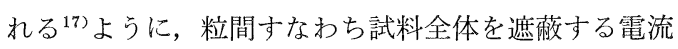
と結晶粒内の遮蔽電流の合成であると考えられる。そ こで試料の電磁特性をさらに解明するために以下のよ うな補助実験を行った。

まず, 微小交流磁界重畳法 ${ }^{18)}$ を用いて磁界侵入長 $\lambda^{\prime}$ の交流磁界振幅 $B_{\mathrm{ac}}$ 依存性を測定した。。交流磁界 は周波数 $35 \mathrm{~Hz}$ で試料軸方向に印加した。結果を Fig. 4 (a) に示す。 $\lambda^{\prime}$ は 0 から磁界振幅 $B_{\mathrm{ac}}$ とともに しだいに増加して $B_{\mathrm{ac}}=0.01 \mathrm{~T}$ で飽和し, 飽和值は 


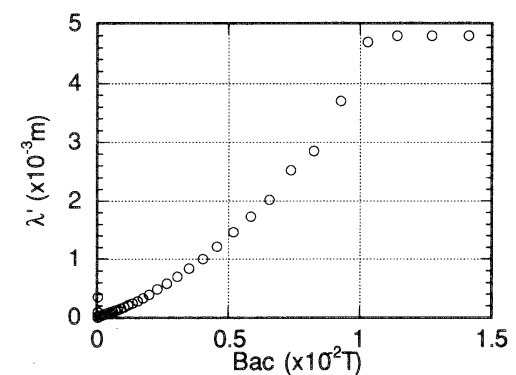

(a)

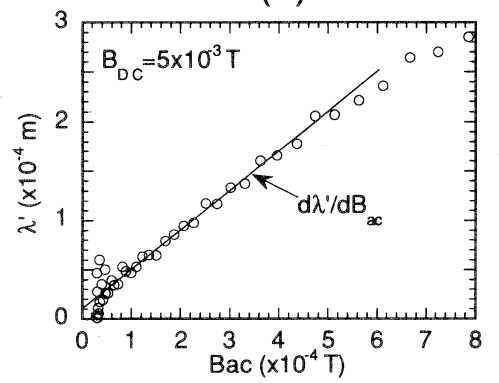

(b)

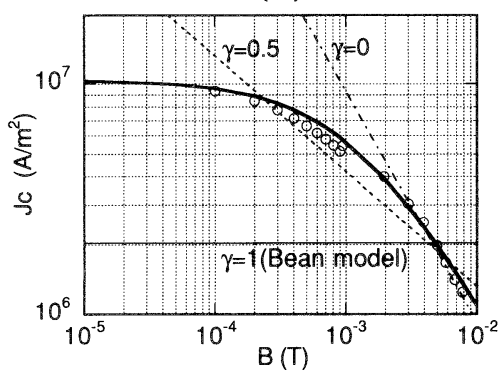

(c)

Fig. 4 (a) Ac penetration depth $\lambda^{\prime}$ versus amplitude $B_{\mathrm{ac}}$ of the ac magnetic field at $B=0 \mathrm{~T}$. (b) Ac penetration depth $\lambda^{\prime}$ versus amplitude $B_{\mathrm{ac}}$ of the ac magnetic field at a bias field of $B_{\mathrm{DC}}=5 \times 10^{-3} \mathrm{~T}$. The critical current density can be estimated by the gradient of the solid line. (c) Dependence of the critical current density $J_{\mathrm{c}}$ on magnetic field $B$ estimated from ac inductive measurement. The theoretical dependence of $J_{\mathrm{c}}$ on $B$ derived from Irie-Yamafuji model are also shown for $\gamma=0,0.5$ and 1 for comparison. The thick solid line represents the approximate expression given by Eq. (10).

試料半径 $4.8 \mathrm{~mm}$ に一致している。次に, $60 \mathrm{~Hz}$ 交流 磁界印加時の交流損失を測定した。測定は正弦波交流 磁界を試料軸方向に印加し磁化測定法 ${ }^{15)}$ により行っ

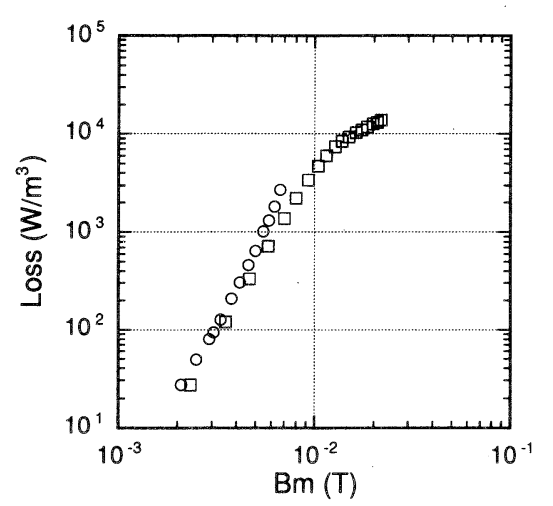

(a)

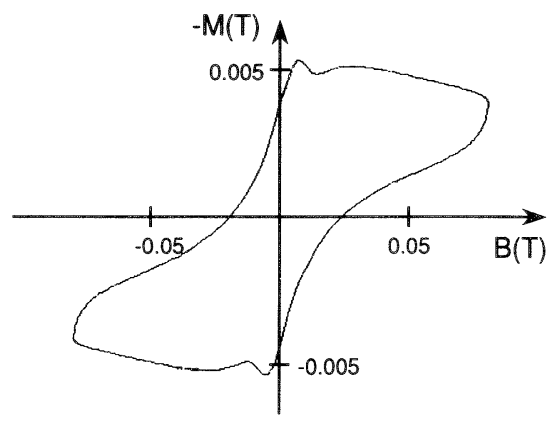

(b)

Fig. 5 (a) AC loss versus amplitude $B_{\mathrm{m}}$ of the ac longitudinal magnetic field with a frequency of $60 \mathrm{~Hz}$. AC losses under carrying ac transport current are replotted by the same symbol $(O)$ as shown in Fig. 3 for comparison. (b) An example of the observed magnetization curve.

た。測定した交流損失の磁界振幅 $B_{\mathrm{m}}$ 依存性を Fig. 5(a) に，また測定した磁化曲線の一例を Fig. 5 (b) に示 す。Fig. 5 (a) に示す損失曲線より中心到達磁界 $B_{\mathrm{p}}$ は 約 0.01 T であることがわかる。Fig. 5 (a) には, Fig. 3 に示した電流通電時の交流損失も表面磁界振幅 $B_{\mathrm{s}}=$ $\left(\mu_{0} I_{\mathrm{m}} / 2 \pi R\right)$ に対して磁界印加時の交流損失と比較し て○印で示している。松下らが行った準静的状況下で の理論計算 ${ }^{12)}$ では, 小振幅領域では両者は一致し, 振 幅 $B_{\mathrm{m}}$ が $B_{\mathrm{p}}$ に近づくにつれ電流通電時の損失が磁界 印加時の損失より大きくなることが示されている。

Fig. 5 (b) に示す磁化曲線は $0.01 \mathrm{~T}$ と $0.03 \mathrm{~T}$ 付近 でピークを持つことから, 本バルク材についても粒 内, 粒閒の二つの遮蔽電流による磁化が混在するもの

低温工 学 
と考えられる。しかし，Fig. 4(a)に抢いてY系酸化物 超電導体でよく観測されるような粒間，粒内の異なっ た遮蔽電流の混在を示寸磁界侵入長 $\lambda^{\prime}$ の 2 段階の増 加17) はみられないこと，また $\lambda^{\prime}$ が飽和する磁界振幅 が損失特性上の中心到達磁界に一致しており，粒間， 粒内の遮蔽電流による磁化が混在していれば容易に数 割は異なる $\lambda^{\prime}$ の飽和値 ${ }^{19)}$ が数\%以下の誤差で試料半 径に一致していること,さらに Fig. 5 (a) において磁 界印加時と電流印加時の交流損失が準静的状況下での 考察ではあるが理論解析と同様に低振幅領域で一致し ていることから，少なくとも中心到達磁界以下の磁界 領域に抢ける電磁現象は, 電流印加時, 磁界印加時と もに輸送電流を担う粒間の電流によるものが支配的で あると判断できる。

以上のような考察結果を踏まえて, 中心到達磁界以 下の磁界にお打る臨界電流密度の磁界依存性を微小交 流磁界重疊法を用いて測定した。まず，0からほぼ 10 gauss 単位で 80 gauss までの直流バイアス磁界を 印加し, 各々のバイアス磁界に対し数ガウスの振幅の 微小交流磁界を重畳して各バイアス磁界に抢ける磁界 侵大長 $\lambda^{\prime}$ の交流磁界振幅 $B_{\mathrm{ac}}$ 依存性を測定した。一 例として直流バイアス磁界 50 gauss の場合の測定結 果をFig. 4 (b) に示す。これより $d \lambda^{\prime} / d B_{\mathrm{ac}}$ を実線の ように近似して, 各バイアス磁界に打ける臨界電流密 度 $J_{\mathrm{c}}$ を $J_{\mathrm{c}}=\left(d \lambda^{\prime} / d B_{\mathrm{ac}}\right)^{-1} / \mu_{0}$ として求めた。ただし, 測定装置の都合上外部磁界は試料軸方向に印加した。 よって得られた $J_{\mathrm{c}}$ は通電電流とは垂直な円周方向の ものである。しかし，Fig. 5(a) に示したように磁界印 加と電流印加の場合の交流損失が小振幅領域でほぼ一 致していることから，輸送電流を担う粒間の $J_{\mathrm{c}}$ につ いて異方性は小さいと考えられる。測定結果を Fig. 4 (c) に○印で示す。10 gauss 以下の $J_{\mathrm{c}}$ は直流バイア ス磁界を印加せずにその磁界と同じ振幅の交流磁界を 印加し平均の $J_{\mathrm{c}}$ として求めたものである。Fig. 4 (c) には従来のピン力モデルに基づく $J_{\mathrm{e}}$ の磁界 $B$ 依存性

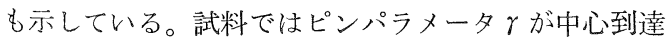
磁界までの低磁界領域で $\gamma=1$ から $\gamma=0$ まで変化し ていることがわかる。

\section{A 数值解析}

前節において，今回製作した $\mathrm{Bi}$ 系バルク材では結 晶粒は存在するものの中心到達磁界以下の低磁界領域 では電磁特性上はバルク材全体のマクロな遮蔽電流が 支配的であること，およびその $J_{\mathrm{c}}$ 特性が従来のピン カモデルとは一致しないことを明らかにした。ここで

Vol. 29 No. 4 (1994)
は, さらに得られた $J_{\mathrm{c}}$ 特性を用いて通電時の電磁界 の数值解析を行う。

円柱導体に電流を流した場合の電磁界は円柱座標系 の 1 次元 Maxwell 方程式,

$$
\left\{\begin{array}{l}
\frac{\partial E_{z}}{\partial r}=\frac{\partial B_{\varphi}}{\partial t} \\
\frac{1}{\mu_{0}} \frac{1}{r} \frac{\partial}{\partial r}\left(r B_{\varphi}\right)=J_{z}
\end{array}\right.
$$

で表される。周波数 $f$, 電流ピーク值 $I_{\mathrm{m}}$ の正弦波交 流電流を通電寸る場合，表面磁界 $B_{\mathrm{S}}$ は，

$$
B_{\mathrm{s}}=B_{\varphi} \mid r=R=\frac{\mu_{0} I_{\mathrm{m}} \sin (2 \pi f t)}{2 \pi R}
$$

と表され，これが境界条件を与える。またこの場合の 交流損失は,

$$
P=\frac{1}{T} \frac{1}{\pi R^{2}} \int_{0}^{T} \int_{0}^{R} J_{\mathrm{z}} E_{\mathrm{z}} 2 \pi r d r d t
$$

として求为られる。 $J_{\mathrm{c}}$ の磁界 $B$ 依存性は Fig. 4 (c) に执いて太実線で示すように,

$$
J_{\mathrm{c}}(B)=\frac{1}{\mu_{0}(65 B+0.07655)}
$$

と近似できる。試料内の局所的電界 $E_{\mathrm{z}}$ と電流密度 $J_{\mathrm{z}}$ の関倸は，(1) 式と（10）式より次式で仮定した。

$$
E_{\mathrm{z}}=10^{-5}\left(\frac{J_{\mathrm{z}}}{J_{\mathrm{c}}(B)}\right)^{26}
$$

（6）（11）式を基礎方程式として差分法により $60 \mathrm{~Hz}$ 通電時の試料内部の電磁界の時間変化と交流損 失の数值解析を行った。初期状態は $t=0$ において $B_{\varphi}=0, E_{\mathrm{z}}=0, J_{\mathrm{z}}=0$ とした。通電電流 $147 \mathrm{~A}$ の場合 の電磁界分布変化の計算結果を Fig. 6 (a) 〜 (e) 亿示す。

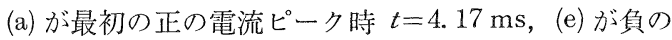
電流ピーク時 $t=12.5 \mathrm{~ms}$ に抢けるものである。いず れの時刻に㧊いても鎖交磁束が多い外側ほど電界は大 きくなっているが， $J_{\mathrm{c}}$ が磁界に依存するため電流分 布の変化は複雑である。ここでは通電電流ピーク值は $147 \mathrm{~A}$ とほ汴臨界電流值であるが，電流はピーク時に も直径のほぼ $40 \%$ 以内には流れていないことがわか る。詳細にみれば, (a)に示す最初の正の電流ピーク時 から磁束拉よび電流分流領域は (b) (c) に示すようにし だいに内部一侵入し，また (e)では負の電流ピーク時 であるにもかかわらず，磁束侵入フロント部では正の 電流領域が残っている。比較のために，周波数のみを $0.1 \mathrm{~Hz}$ として計算した電磁界のほぼ電流ピーク時 $t=$ $2.36 \mathrm{~s}$ における分布を Fig. 6 (f) に示している。電流 は中心部まで流れている。すなわち, $60 \mathrm{~Hz}$ 交流通電 

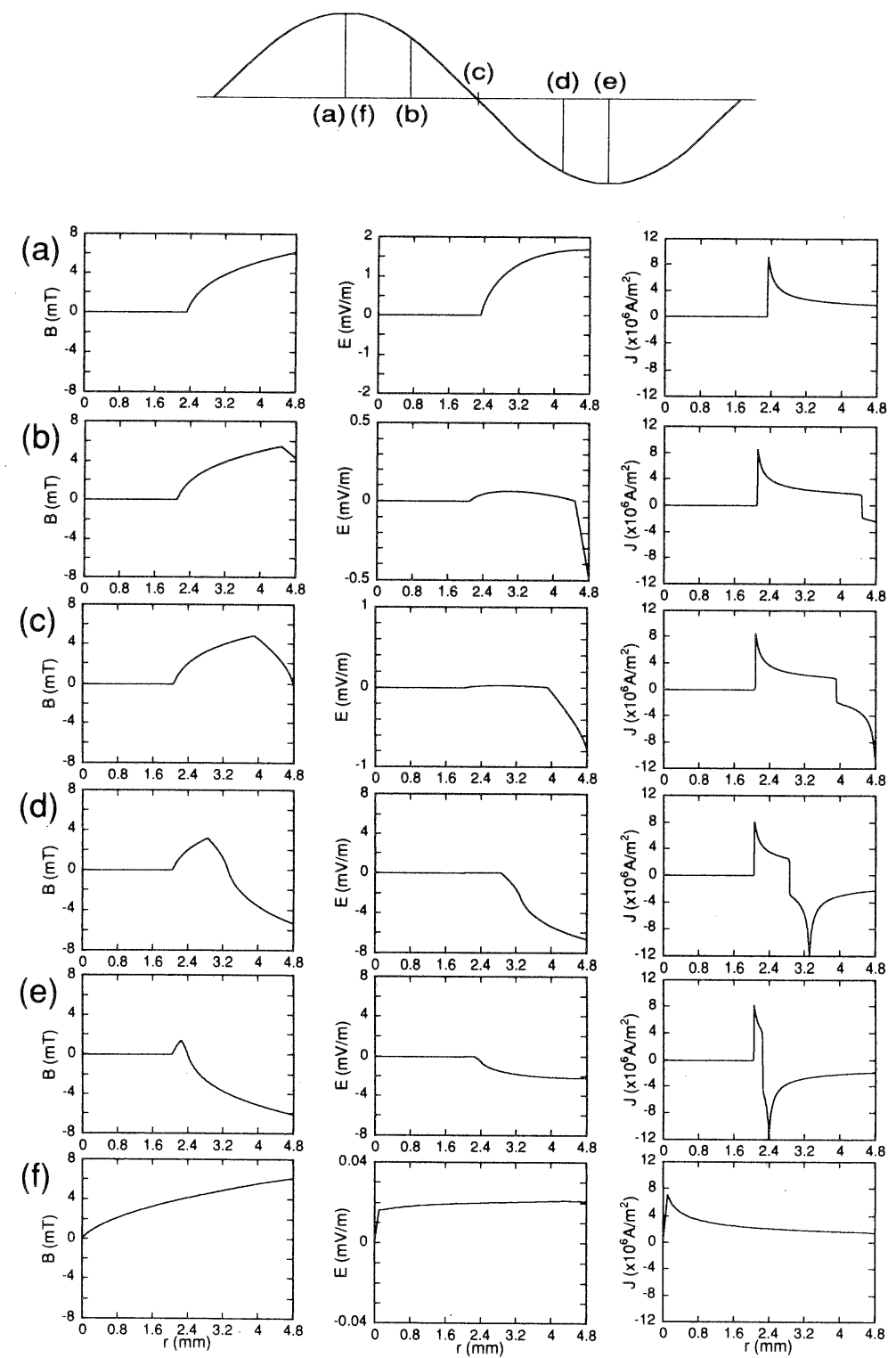

Fig. 6 Numerically calculated distribution of the magnetic field $B(r)$, electric field $E(r)$ and current density $J(r)$ inside the superconducting cylinder carrying ac transport current with a amplitude of $147 \mathrm{~A}$ and a frequency of (a) (e) $60 \mathrm{~Hz}$ and (f) $0.1 \mathrm{~Hz} . t=$ (a) 4.17 , (b) 6.25 , (c) 8.33 , (d) 11.1 , (e) 12.5 and (f) $2.5 \times 10^{3} \mathrm{~ms}$. Initial conditions assumed here are $B=$ $E=J=0$ inside of the cylinder at $t=0$.

時には狭義の臨界状態モデルによる電磁界の準静的分 布からのはずれが大きいことがわかる。これは外周部 に扔ける電界が臨界電流值を定義した電界より数十倍 から数百倍も大きいためである。具体的には表面電界 $\left|E_{\mathrm{s}}\right|$ は Fig. 6(d)に示す $t=11.1 \mathrm{~ms}$ において最大とな
る。この時の表面磁界 $\left|B_{\mathrm{s}}\right|$ は $5.3 \times 10^{-3} \mathrm{~T}$ であり， これに対応する臨界電流密度 $J_{\mathrm{c}}$ は Fig. 4 (c) より 1.74 $\times 10^{6} \mathrm{~A} / \mathrm{m}^{2}$ であるが，表面付近では電界が $6.65 \mathrm{mV}$ $/ \mathrm{m}$ にも達するために $2.20 \times 10^{6} \mathrm{~A} / \mathrm{m}^{2}$ とこの磁界に おける $J_{\mathrm{c}}$ の 1.26 倍に相当する密度で電流が流れて 


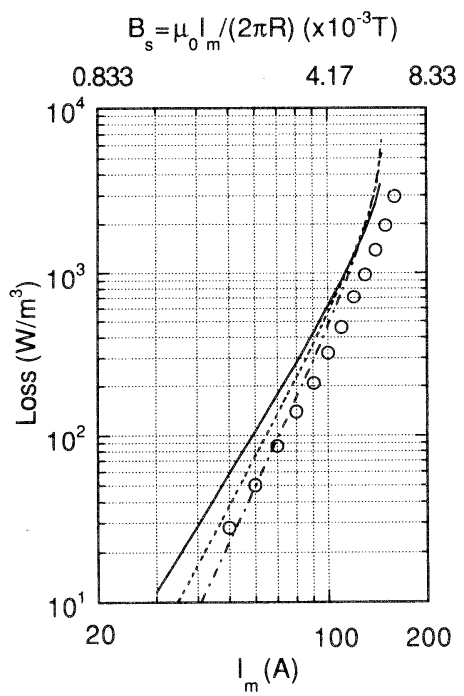

Fig. 7 AC loss versus peak value $I_{\mathrm{m}}$ of the ac current with a frequency of $60 \mathrm{~Hz}$. Symbols represent the observed results and the solid line represents the numerically calculated results.

いることがわかる。

これは損失の面では超電導体の臨界電流密度が大き くなったことと等価である。磁界印加の場合にはよく 知られているが, この場合も磁界振幅は中心到達磁界 以下であるから試料全体で平均した単位体積当たりの 交流損失は臨界電流密度が大きくなるにつれ小さくな $3^{12,20,21)}$ 。数值解析によって得られた交流損失の電流 值依存性を測定結果と比較して Fig. 7 に示している。 計算結果は測定值とほぼ一致しているとみなしてよ い。わずかな誤差は計算上 (11) 式のように $E-J$ 特 性の $n$ 值を磁界によらず一定にしたためと考えられ る。

\section{4. 考察}

3 章において，断面寸法が大きな酸化物超電導の交 流損垁解析には狭義の臨界状態モデルが適用できない ことを明らかにした。ここでは一般的な円柱状超電導 体について， $E-J$ 特性を次式のように $n$ 值を用いて近 似し，交流通電時に発生する交流損失の周波数および $n$ 值依存性を数值解析により考察する。

$$
E=10^{-5}\left(\frac{J}{J_{\mathrm{c}}}\right)^{n}
$$

クライテリオンは $10^{-5} \mathrm{~V} / \mathrm{m}=0.1 \mu \mathrm{V} / \mathrm{cm}$ とした。電

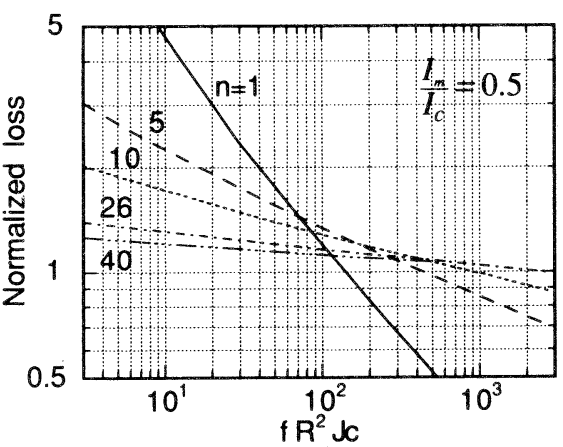

(a)

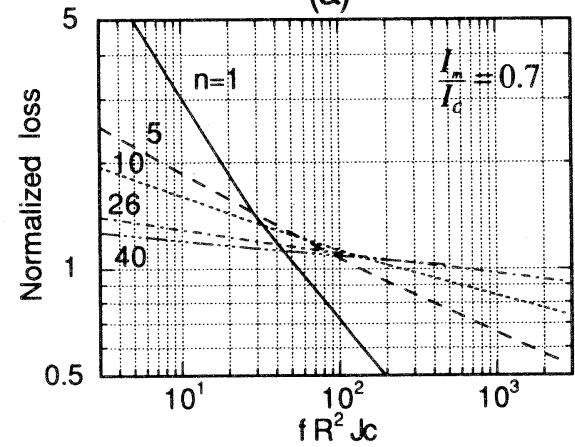

(b)

Fig. 8 Numerically calculated dependences of $\mathrm{AC}$ losses of the superconducting cylinders with a radius of $R$ and a critical current density of $J_{\mathrm{c}}$ under carrying ac transport current with a frequency of $f$ on $f R^{2} J_{\mathrm{c}} \quad i=$ (a) 0.5 , (b) 0.7 . Criterion of the critical current density and pinning parameter $\gamma$ assumed here are $0.1 \mu \mathrm{V} / \mathrm{cm}$ and 1 , respectively. AC losses are normalized by the theoretical results from the Bean's type critical state model expressed by Eqs. (13) and (14).

流通電時に超電導体内部に発生する電界は超電導体の 半径 $R, E-J$ 特性および周波数 $f$ に依存する。簡単化 のために Bean モデルを採用し（12）式において臨界 電流密度 $J_{\mathrm{c}}$ を一定とした場合, 交流損失は, 次式で 記述される従来の電流通電時の履歷損失の理論值で規 格化すると，付録に示すように $f R^{2} J_{\mathrm{c}}$ の関数として 表される。

$$
\begin{aligned}
& W=\mu_{0} f R^{2} J_{\mathrm{c}}^{2} h(i) \\
& i=\frac{I_{\mathrm{m}}}{I_{\mathrm{c}}}, h(i)=i\left(1-\frac{i}{2}\right)+(1-i) \ln (1-i)
\end{aligned}
$$

これは Bean モデルを用いて準静的状況すなわち狭義 
の臨界状態モデルを仮定した場合の交流通電時の単位 体積単位時間当たりの履歴損失の理論表式である ${ }^{9,12)}$ 。

そこで $n=1,5,10,26,40$ の場合について規格化 された交流損失の $f R^{2} J_{\mathrm{c}}$ 依存性を数值計算により求 めた。結果を Fig. 8 に示す。Fig. 8 (a) は $i=0.5$, (b) は $i=0.7$ の場合である。いずれの場合も周波数 $f$, 半径 $R$, 臨界電流密度 $J_{\mathrm{c}}$ が大きくなるにつれ, 交流 損失の従来の理論值に対する比は小さくなる。 $n$ 值が 小さいほどその $f R^{2} J_{\mathrm{c}}$ 依存性は大きく, $n$ が40 と大 きい場合には比は 1 に近く $f R^{2} J_{\mathrm{e}}$ 依存性は小さい。 低 $f R^{2} J_{\mathrm{c}}$ 領域では $n$ 值が小さいほど内部への侵入磁 束が多いために交流損失は従来の理論值より大きくな っている。

ここではクライテリオンを $0.1 \mu \mathrm{V} / \mathrm{cm}$ としたが, Fig. 8 の縦軸の值はクライテリオンにより変化する。 クライテリオンを $1 \mu \mathrm{V} / \mathrm{cm}$ とすると, $J_{\mathrm{c}}$ は $n=26$ の場合 $10^{1 / 26}=1.093$ 倍, $n=10$ の場 合 $10^{1 / 10}=1.259$ 倍に大きくなる。これに応じて，(13）式の狭義の臨 界状態モデルを仮定した理論值は， $i$ が一定の場合， それぞれ約 1.2 倍, 1.6 倍となる。しかし, 通電電流 が $J_{\mathrm{c}}$ に比例して大きいため実際の交流損失もそれ以 上に大きくなり, 縦軸に示す比の值は, $i=0.5$ の場 合にはそれぞれ 1.3 倍， 2 倍， $i=0.7$ の場合には 1.4 倍, 2.2 倍に大きくなる。このようにクライテリオン を大きくすると低 $f R^{2} J_{\mathrm{c}}$ 領域では $n$ 值が小さいほど 理論表式との差がさらに大きくなる。

\section{5. まと め}

本研究では，まず試作した Bi 系バルク超電導体の $60 \mathrm{~Hz}$ 交流通電時の交流損失を液体窒素中で測定し て, 従来の準静的状況を仮定して導出された履歷損失 の理論表式と比較し, 画者の相違の原因を補助実験を 交えて考察した。その結果, 交流通電時に発生する電 界は, 磁気的不安定性条件が緩やかな液体窒素温度領 域で動作する酸化物超電導体では, 通常臨界電流值を 規定する電界より容易に数桁も大きくなること，ま た, そのために交流通電時には $n$ 值の小さな酸化物超 電導体では電界に応じて臨界電流密度より数十\%も大 きな密度で電流が流れうる，すなわちこのような酸化 物超電導体の交流損失解析には狭義の臨界状態モデル がよい近似で適用できないことを明らかにした。そこ で, $E-J$ 特性が $n$ 值を用いて近似できる一般的な円柱 状超電導体について, 交流通電時の交流損失の周波 数, 臨界電流密度, 半径依存性を数值解析により求
め, 準静的状況を仮定して導出された従来の理論表式 との差を定量的に評価した。

また，測定した交流損失の定量性を評価するには， 微小交流磁界重畳法による中心到達磁界以下での臨界 電流密度の測定が必要であることも示唆した。

臨界電流密度を一定とする Bean モデルに基づき準 静的状況を仮定して導出された従来の履歷損失の理論 表式（13）式にゼロ磁界中で測定した臨界電流密度を 代入して求められる計算值は, バルク超電導体を用い て電流リードゃケーブルを設計するうえでの一応の目 安となる。しかし，実際の交流損失值は周波数が高い ほど，また試料の直径および臨界電流密度が大きいほ ど小さくなり，逆の場合には大きくなる。n值が小さ いほど,従来の理論值からのはずれは大きくなりうる。

本論文では円柱形状超電導バルク材の交流通電時の 交流損失について考察を行ったが，電流リード用 $\mathrm{Bi}$ 系バルク材としては $1 \times 10^{7} \mathrm{~A} / \mathrm{m}^{2}$ を越える高い臨界 電流密度を持つ円筒形状のものも開発されている11。 円筒形状超電導体に通電する場合, 同じ臨界電流密度 と電流容量を持つ円柱形状超電導体と比較して, 中空 部分に磁束は侵入せずまた自己磁界も低いため, 発生 する電界は小さく，交流損失の従来の理論值からのは ずれも大きくはないと考えられる。

付 録

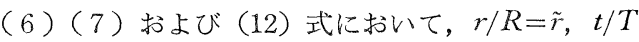
$=\tilde{t}, J_{\mathrm{z}} / J_{\mathrm{c}}=j, E_{\mathrm{z}} / R^{2}=e, B_{\varphi} /\left(J_{\mathrm{e}} R\right)=b$ と規格化を行 う, 次の $j$ についての方程式が導かれる。

$$
\frac{1}{\tilde{r}} \frac{\partial}{\partial \tilde{r}}\left(\tilde{r} \frac{\partial j^{n}}{\partial \tilde{r}}\right)=\frac{\mu_{0} f R^{2} J_{\mathrm{c}}}{10^{-5}} \frac{\partial j}{\partial t}
$$

ここで $T$ は周期で $T=1 / f$ である。また，境界条件 (8) 式は $i$ の関数であるから, $j$ は $\tilde{r}, \tilde{t}, i, n, f R^{2} J_{\mathrm{c}}$ の関数であり交流損失 (9) 式は,

$$
\begin{aligned}
P & =2 J_{\mathrm{c}} R^{2} \int_{0}^{1} \int_{0}^{1} e j \tilde{r} d \tilde{r} d \tilde{t}=2 J_{\mathrm{c}} \int_{0}^{1} \int_{0}^{1} 10^{-5} j^{n+1} \tilde{r} d \tilde{r} d \tilde{t} \\
& \equiv 2 J_{\mathrm{c}} F\left(i, n, f R^{2} J_{\mathrm{c}}\right)
\end{aligned}
$$

と表される。これを従来の履歴損失の理論表式 (13) 式を用いて規格化すると，

$$
\frac{P}{W}=\frac{2 J_{\mathrm{c}} F\left(i, n, f R^{2} J_{\mathrm{c}}\right)}{\mu_{0} f R^{2} J_{\mathrm{c}}{ }^{2} h(i)} \equiv G\left(i, n, f R^{2} J_{\mathrm{c}}\right)
$$

となる。これは $i, n$ が一定の場合には $f R^{2} J_{\mathrm{c}}$ のみの 関数である。 
参考 文 献

1) 山田 豊, 長谷部次教, 柳谷知之, 直原和哲, 石塚正之, 安原征治, 石原 守: 低温工学 28 (1993) 86

2) P. F. Herrmann, C. Albrecht, J. Bock, C. Cottevieille, S. Elschner, W. Herkert, M-O. Lafon, H. Lauvray, A. Leriche, W. Nick, E. Preisler, H. Salzburger, J-M. Tourre and T. Verhaege: IEEE Trans. Applied Superconductivity 3 (1992) 876

3) F. Irie and K. Yamafuji: J. Phys. Soc. Japan 23 (1967) 255

4) C. P. Bean: Phys. Rev. Lett. 8 (1962) 250

5) H. London: Phys. Lett. 6 (1963) 162

6) J. Silcox and R. W. Rollins : Rev. Mod. Phys. 36 (1964) 52

7) Y.B. Kim, C. F. Hempstead and A.R.Strnad: Phys. Rev. 129 (1963) 528

8) C. P. Bean: Rev. Mod. Phys. 36 (1964) 31

9) R. Hancox: Proc. IEE 113 (1966) 1221

10) D. J. Hanrahan : IEEE Trans. Magn. MAG-6 (1970) 833

11) H. F. Taylor: Phys. Rev. 165 (1968) 517
12）松下照男, 住吉文夫, 竹尾正勝, 入江冨士夫： 九大工学集報 51 (1978) 47

13）松下照男：低温工学 24 (1989) 83

14）宇野直樹, 三村正直, 木下 隆, 田中靖三，植 田和雄, 滝田 清, 上出俊夫 : 古河電工 時 報 No.91 別冊 (1992.12) 6

15）住吉文夫，山口泰郎，川畑秋馬，船木和夫，岩 熊成卓：低温工学 27 (1992) 339

16）例として野田 稔, 船木和夫, 山藤 馨：九大 工学集報 57 (1984) 805

17) T. Matsushita, B. Ni and K. Yamafuji: Adv. Cryog. Eng. Mater. 36 (1991) 403

18) A. M. Cambell : J. Phys. C 2 (1969) 1492

19) B.Ni, T.Munakata, T.Matsushita, M.Iwakuma, K. Funaki, M. Takeo and K. Yamafuji: Jpn. J. Appl. Phys. 27 (1988) 1658

20) W. J. Car, Jr.: AC Loss and Macroscopic Theory of Superconductors, Gordon and Breach, Science Publishers, Inc., New York (1983) Eqs. (5-2) and (5-13) in Chapter 5

21) 電気学会大学講座 超電導工学(改訂版), 4.8.2 項 特に (4.77) 式 